\title{
Sustainability Impact Assessment of Forest Operations: a Review
}

\author{
Janine Schweier ${ }^{1} \cdot$ Natascia Magagnotti $^{2} \cdot$ Eric R. Labelle $^{3} \cdot$ Dimitris Athanassiadis $^{4}$
}

Published online: 1 July 2019

(C) The Author(s) 2019

\begin{abstract}
Purpose of Review One of the challenges of forest operations is to consider the consequences of different management strategies and to estimate the economic, environmental and social performance of different processes, products, or services. From the methods available to quantify the impact of alternative forest management, we selected the method of Sustainability Impact Assessment (SIA), an iterative process that includes the analysis of the societal, environmental, and economic sustainability pillars and offers a wider assessment framework, which is useful for stakeholders and policy makers. The purpose of this review is to identify the state of the art and trends of SIA in forest operations.

Recent Findings There are few studies including all pillars of sustainability and most of the studies consider different aspects of environmental or economic impacts. It is important to determine the system boundaries and select the appropriate indicators in order to have a comprehensive SIA. Different harvesting technologies and their deployment can influence costs, productivity, environment, and safety risk. Some indicators, such as cost and productivity, can vary between countries and different scenarios. Summary Efficient machines, appropriate technical systems, innovative products, and up-to date training of operators can have a positive impact on sustainability. Economic factors can change at a rapid pace, and new machines can play a positive role in forest operations (e.g., lower fuel consumption, higher level of safety and comfort for operators). The inclusion of indicators measuring the extra value of the forest should be considered. We suggest adopting sensitivity analysis during the assessment of key processes to observe the effect on the hot spots.
\end{abstract}

Keywords Sustainable management $\cdot$ Bioeconomy $\cdot$ LCA $\cdot$ Logging $\cdot$ GHG $\cdot$ Indicators

This article is part of the Topical Collection on Forest Engineering

Janine Schweier

Janine.schweier@foresteng.uni-freiburg.de

$\triangle$ Eric R. Labelle

eric.labelle@tum.de

Natascia Magagnotti

magagnotti@ivalsa.cnr.it

Dimitris Athanassiadis

Dimitris.athanassiadis@slu.se

1 University of Freiburg, Werthmannstraße 6, 79085 Freiburg, Germany

2 CNR, IVALSA, Via Madonna del Piano 10, 50019 Sesto Fiorentino, FI, Italy

3 Department of Ecology and Ecosystem Management, Technical University of Munich, Hans-Carl-von-Carlowitz-Platz 2, 85354 Freising, Germany

4 Department of Forest Biomaterials and Technology, Swedish University of Agricultural Sciences, Umeå, Sweden

\section{Introduction: Sustainable Development}

Within the last four decades, the idea of "Sustainable Development" (SD) has appeared as a major topic on international policy agendas. Nowadays, the concept of sustainability is being increasingly applied in policy development to offer support for decision-making and to improve environmental, societal, and economic performances of processes, products, or services (Fig. 1). In the 1980s, the World Commission on Environment and Development (WCED) was already studying the future prospects of the human species from a rather holistic perspective and suggested long-term environmental, social, and economic strategies for policy makers. Then, in 1992, the UN General Assembly decided to host the UN Conference on Environment and Development (UNCED) in Rio de Janeiro, also known as the Earth Summit, where the attending states and organizations defined SD as a concept based on the three pillars in consideration of ecological sustainability as well as the desirable economic and social development [1]. The next major achievement was the UN Conference on Sustainable Development, known as Rio + 
Fig. 1 Schematic overview illustrating the relationship between the sustainability indicators and impact assessment methods that can be applied to evaluate operations and management decisions in order to support sustainable development

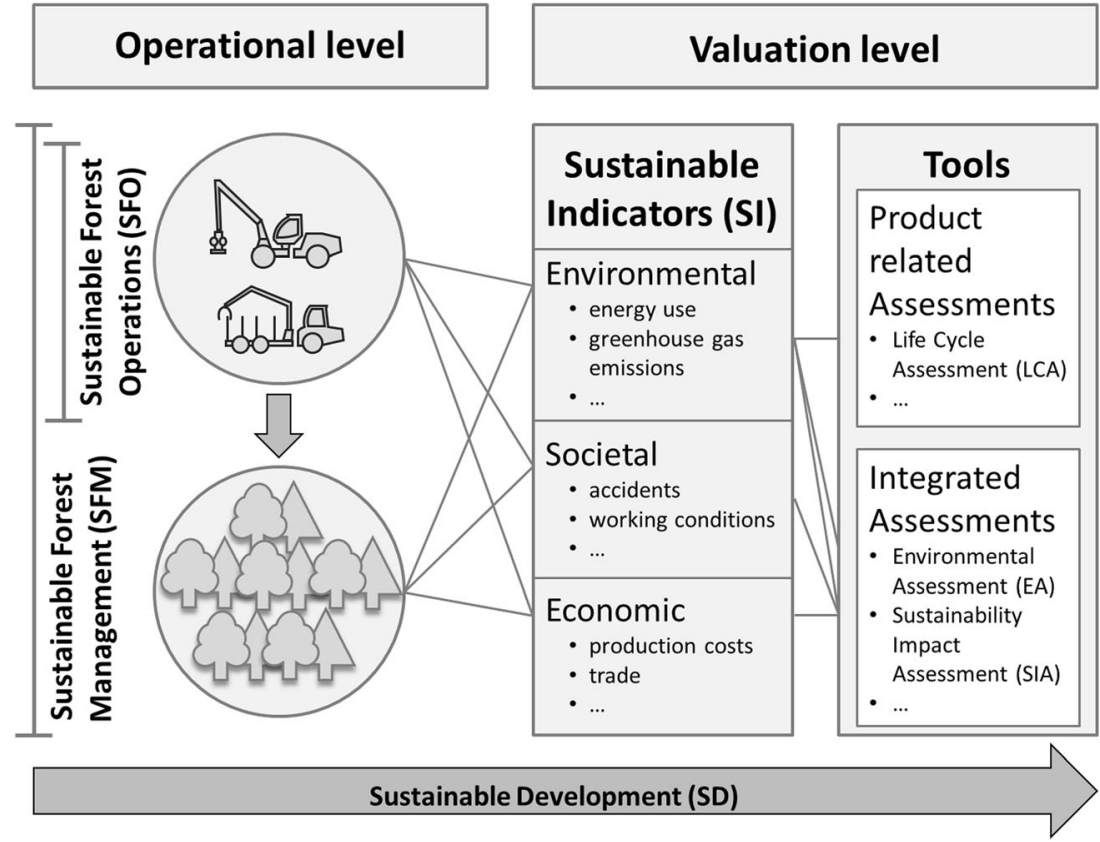

20, which took place in Rio de Janeiro in 2012 and resulted in a focused political document entitled "The future we want" [2]. The Paris Agreement was decided 3 years later in 2015. It became famous particularly due to its primary goal "to strengthen the global response to the threat of climate change" [3]. Taking action to combat climate change and its impacts is one of the 17 Sustainable Development Goals (SDGs) being formulated within the recent strategy entitled "The 2030 Agenda for Sustainable Development" [4]. This agenda went beyond the "simple wish list" of previous conferences [5], because concrete targets and indicators as well as complexity and interactions were addressed. All the above-mentioned actions, agendas, and strategies aim to support progress towards sustainability. Today, in 2019, many projects and initiatives are ongoing, such as the revision process of social criteria and the transition to a circular economy.

\section{Evaluation Tools}

After the implementation of SD, there was a need to create tools to evaluate applied strategies. As a consequence, tools - understood as methods - were required that address the decision-support challenges "interpretation, informationstructuring and influence" [6]. Ness et al. [7], and more recently Karvonen et al. [8], provided an overview and categorized existing evaluation tools into different groups (Fig. 1). Among them were product-related assessment tools such as the wellknown Life Cycle Assessment (LCA) focusing on material and energy flows. LCA is mainly used to compare the environmental impacts of alternative goods and services. Integrated assessment tools such as the so-called Environmental Impact Assessment (EIA) and the Sustainability Impact Assessment
(SIA) belong to another group (Fig. 1). In general, and this is also our interpretation of the term, impact assessment is a method to evaluate (assess) potential consequences (impacts) of actions. It is applied when impacts of proposed changes should be taken into account, for example, how changes in policy or technological innovation influence the different aspects of sustainability [9]. Thus, it is used for supporting decision-making and developing integrated policies that "take full account of the three sustainable development dimensions" and include the "cross-cutting, intangible and long-term considerations" of those policies [10].

Ness et al. [7] described the impact assessments as "a small group of forecasting tools used for improving the basis for policymaking and project approval process". This group was developed further and now also includes, for example, the carbon footprint of products [11] and the ecosystem services valuation [12]. A comprehensive overview about common tools was published by the National Research Council of the USA [13] and by Taisch et al. [14]. However, tools addressing all pillars of sustainability in an equal way and providing decision support are scarce. Sieber et al. [15] presented SIA tools for policy advice with special regard to land use. In the context of forestry, the software ToSIA (Tool of Sustainability Impact Assessment) was introduced and discussed [16-19] and applied following the first years after development at least by $[20-24]$ to assess the sustainability of alternative forestwood chains and wood products.

\section{Sustainability Impact Assessment}

The unique feature of a SIA is that all dimensions of sustainability are addressed (Fig. 1). A SIA has two main functions: 
First, it is a "systematic and iterative process [...] of the likely economic, social and environmental impacts of policies, plans, programs and strategic projects [...] [aiming] to improve the performance of the strategies by enhancing positive effects, mitigating negative ones and avoiding that negative impacts are transferred to future generations" [25]. Second, it is a policy instrument to better identify the "positive and negative impacts of proposed policy actions" [25] before they have been formulated and thus, SIA allows informed decisions to be made [10].

Sustainability is very complex, multi-dimensional, and includes uncertainties and risks [6]. Therefore, SIA seems to be a suitable method for assessing potential impacts of management strategies and single operations. Most of the abovementioned methods can be used as stand-alone but can also be easily integrated into or applied upon a SIA (e.g., a LCA could be carried out within a SIA to assess environmental impacts).

\section{Sustainable Forest Management and Sustainable Forest Operations}

Forest management strategies supporting the aims of SD have been developed and applied. We noticed that recent studies use the term "Sustainable Forest Management" (SFM) [26, 27] as an ideal practice in managing forest ecosystems and their services [28]. The concept of SFM is based on the principles of SD aiming to use "forests and forest lands in a way, and at a rate, that maintains their biodiversity, productivity, regeneration capacity, vitality and their potential to fulfill, now and in the future, relevant ecological, economic and social functions" [c.f. 27] (Fig. 1). Sustainable Forest Management concentrates more on the management aspects themselves rather than on the decision support to operationalize SFM. The same is true for "Sustainable Forest Operations" (SFO), which focus on logging, thus, on the partial forest-wood chain from forest stand to road side (Fig. 1). Marchi et al. [29•] argued that an "effective implementation of SFM practice depends on carrying out forest operations in a sustainable manner'. To conclude, each process within the entire production chain should be carried out as best as possible. When focusing on SFO, this might be, i.e., the use of flexible machines operating in complex stands with sensitive soils, low-emission technologies, operations with enhanced working conditions, and low risks of fatal accidents.

From a management perspective, the major challenges are (i) to identify and compare alternative production chains; (ii) to estimate the social, environmental, and economic performances; and (iii) to evaluate and judge results. The latter is the most important difference between SFO/SFM and SIA. With that in mind, we focused on applications of SIA with regard to forest operations (FOs).

\section{Aim of the Review}

This review aims to identify developments and trends of SIA that were carried out for FO. In detail, the review was conducted focusing on the following research questions:

1. Which studies conducted a SIA of FO; which processes along the entire forest-wood supply chain were considered; how did system boundaries differ?

2. Which tools were used for the analysis and which indicators were considered as important?

3. Which further methods were applied upon the SIA to provide a comprehensive basis for decision-makers?

4. Can suggestions be concluded in order to enhance the quality of SIA related to FO?

\section{Materials and Methods}

\section{Literature Research}

Systematic reviews have the advantage of including all studies in order to collect and screen the overall research in a specific field [30], but it turned out that when using the search strings "Sustainability Impact Assessment" AND "Forest Operations" (YR 2008-2018), several thousand findings appeared (e.g., 18,900 in Google Scholar; 15,249 in Science Direct) and most of them were not related to the addressed topic. Therefore, we decided to further limit the search strings and to perform a narrative review for each pillar of sustainability, namely the environmental, the economic, and the societal one. Although soil compaction belongs to the environmental category, it was reported separately due to the high number of articles dealing with the technical process of compaction.

Thus, the literature research was conducted according to these categories:

- "Environmental Assessment" AND "Forest Operations"

- "Soil compaction" AND "Forest Operations"

- "Societal Assessment" AND "Forest Operations"

- "Economic Assessment" AND "Forest Operations"

Findings were reported per category. The research was performed using the databases Science Direct, ISI Web of Knowledge, and Google Scholar to retrieve available studies since they comprise a large number of scientific journals. The following criteria were used when undertaking the search:

- We considered only studies that were published between 2008 and 2018, in order to reflect the actual state of the art and recent developments

- Focus on Europe and North America 
- Studies included the name of the category together with the term "forest operations" in the title, abstract, or in the keywords

- Studies were peer-reviewed or original research articles in English. Project reports or conference contributions were not included

Review papers were considered but reported separately from the primary literature. The identified studies were subsequently analyzed in a descriptive manner, including a general description of the study and its target, an overview about considered processes, operations, and machines.

\section{Definition of Forest Operations}

Forestry plays an important role in a low carbon society: the forest production chain provides a multitude of products (e.g., round wood, poles, energy wood) and ecosystem services (e.g., recreation, protection of natural hazards). It includes all processes from site preparation, site tending, silvicultural, and transport operations until the raw material is delivered to a consumer, plant, or farm gate [31•]. However, the single process of FO concentrates on the partial forest-wood chain that includes the felling and extracting processes. Generally, it is distinguished between the three primary logging methods: cut to length (CTL), tree length (TL), full tree (FT) (also known as whole-tree) [32]. All methods can be deployed with different levels of mechanization: motor-manually (MM), semimechanized (SM), or fully mechanized (FM).

\section{Development of Sustainability Indicators}

In the forest-based sector, sustainability concepts with their associated principles and sustainability indicators (SI) were developed 300 years ago [33] and were operationally implemented and further refined through a continuous process. The main drivers were policy [e.g., 34-37] and, as stated in the review by Linser et al. [38], were often in partnership with civil society and international organizations "to develop, approve and implement specific sets of regional and international criteria and indicators to evaluate sustainability of forest management" [38, c.f. 39].

Data can be collected from field studies (from earlier studies or purposefully organized), modeling results and inquiries or statistics [21, 40-42]. Sustainability indicators should be relevant to the topic and balanced with regard to economic, environmental, and social sustainability, as well as feasible in terms of data availability and quality $[41,43,44]$. For the assessment, it is fundamental to clearly define the system boundaries, select the proper indicators, and describe them in order to measure and determine their impacts [31]. To summarize, the selection of indicators is crucial for the quality of decision-support tools $[9,39]$.

\section{Results}

\section{Descriptive Analysis}

In total, 109 studies relating to FO were identified and included at least one of the studied categories of sustainability. Thereof, 46 studies and 6 reviews fulfilled the defined criteria and have been reviewed (Table 1). On average, each publication analyzed four SI. More specifically, 17 studies reported 1-3 SI, 21 studies focused on 4-6 SI, and 8 studies considered more than 6 SI (Table 1).

The review papers were either focused on a specific topic [e.g., 45, 46] or provided a broad overview, while considering many SI [e.g., 8•, 29•]. The latter is a comprehensive review aiming to explore the most important and relevant SI and impact assessment methods to support decision-making in a forest-based bioeconomy.

The majority of the studies were focused on environmental aspects: the most frequently used SI was greenhouse gas emissions/carbon stock/global warming potential ( $n=28$ plus 2 reviews), followed by energy use/cumulative energy demand ( $n=19$ plus 2 reviews) (Table 1). Next, 17 studies and 5 reviews considered accidents/safety and health/human toxicity potential, which belong to the societal pillar of sustainability (Table 1). Marchi et al. [29•] noted that in addition to common indicators such as productivity and fuel consumption, ergonomics, and work quality also need to be considered. We identified four studies [47-50] and four reviews [29•, 46, 51,52] considering working conditions (Table 1).

\section{Environmental Impacts of Forest Operations}

Forest operations commonly involve the use of machinery in the forest environment, which might cause environmental impacts both through the impact of the machinery (e.g., on soils, remaining trees) and through the tailpipe exhaust emissions. The method of LCA was used to determine potential environmental impacts in many of the reviewed studies. LCA provides a structured and comprehensive way to present material and energy flows and their associated emissions.

We noticed few differences regarding the system boundaries reported in the reviewed articles. According to the standard, each LCA follows the "cradle-to-grave" approach, meaning that potential impacts associated with a product are considered throughout its entire life cycle starting from raw material extraction, passing through different processes of manufacture, to product disposal at the end of use [53]. Thus, upstream processes should be considered, but we noticed that the production of machinery and materials (e.g., harvester, lubricants) as well as infrastructure (e.g., forest roads) are usually not included due to the lack of data. Harvesting operations and the transport of the logs to the forest landings are included in all studies that were reviewed. 
Table 1 Reported sustainability indicators in the considered studies

\begin{tabular}{|c|c|c|c|}
\hline $\begin{array}{l}\text { Indicator } \\
\text { category }\end{array}$ & Sustainability indicator & Score & Indicators used in references no. \\
\hline \multirow[t]{5}{*}{ Societal } & Accidents; safety and health; human toxicity potential & 22 & $\begin{array}{l}{[8 \cdot, 16,22,29 \cdot, 46-52,54,55,60,64,68,70,} \\
\quad 87-91]\end{array}$ \\
\hline & Education and training & 4 & {$[51,52,87,88]$} \\
\hline & Working conditions & 8 & {$[29,46-52]$} \\
\hline & Employment & 10 & {$[8 \cdot, 16,21,22,29 \cdot, 41,51,74,89,91]$} \\
\hline & Risk of negative profit & 1 & {$[90]$} \\
\hline \multirow[t]{10}{*}{ Environmental } & Energy use; cumulative energy demand & 21 & $\begin{array}{l}{[9,16,21,22,29 \cdot, 40,41,45,55,57,59,61,63,} \\
\quad 64,66,69,71-74,91]\end{array}$ \\
\hline & Greenhouse gas emissions; carbon stock; global warming potential & 29 & {$[8 \cdot, 9,16,21,22,40,41,45,54-64,66-74,90,91]$} \\
\hline & Generation of waste; waste treatment & 1 & {$[29]$} \\
\hline & forest damage & 1 & {$[29]$} \\
\hline & $\begin{array}{l}\text { Air pollution; air quality; photochemical oxidant formation; ozone } \\
\text { depletion }\end{array}$ & 16 & {$[8 \cdot, 29 \bullet, 54-56,60,62-64,66-71,91]$} \\
\hline & Water use and water quality & 15 & {$[8 \cdot, 29 \bullet, 54-56,62-64,66-71,91]$} \\
\hline & Energy generation & 7 & {$[9,42,60,64,66,74,90]$} \\
\hline & Forest resources; substitution of fossil fuels; fossil depletion & 14 & {$[8 \cdot, 29 \bullet, 57,58,61-64,67-70,90,91]$} \\
\hline & Land use and construction of roads; road maintenance & 6 & {$[8 \cdot, 16,61,67-69]$} \\
\hline & Biodiversity & 2 & {$[8 \cdot, 29 \bullet]$} \\
\hline \multirow[t]{14}{*}{ Soil compaction } & Soil quality (nutrients, eutrophication, acidification) & 15 & {$[29 \bullet, 54-56,62-64,66-72,91]$} \\
\hline & Distribution of applied loads & 1 & [86] \\
\hline & Machine load distribution & 1 & {$[85]$} \\
\hline & Penetration resistance & 4 & [77-80] \\
\hline & Bulk density & 8 & {$[75,77-79,82,84,88,91]$} \\
\hline & Traffic & 7 & {$[75,77-79,83,84,88]$} \\
\hline & $\mathrm{CO}_{2}$ concentration & 1 & {$[84]$} \\
\hline & Gas diffusion coefficient & 1 & {$[84]$} \\
\hline & Shear strength & 1 & [79] \\
\hline & Structure from motion; volume of ruts/bulges; change of total soil volume & 3 & {$[78,79,83]$} \\
\hline & Porosity & 2 & {$[79,82]$} \\
\hline & Soil infiltration/ Infiltration capacity & 2 & {$[77,82]$} \\
\hline & recovery & 2 & {$[75,84]$} \\
\hline & Soil structure/soil texture & 1 & {$[82]$} \\
\hline \multirow[t]{9}{*}{ Economic } & Production costs & 9 & {$[16,21,22,40,51,69,72,74,91]$} \\
\hline & Costs labor & 5 & {$[22,40,57,72,74]$} \\
\hline & delays in work process & 4 & {$[40,51,52,91]$} \\
\hline & gross domestic product & 2 & {$[8 \cdot 16]$} \\
\hline & Trade & 3 & {$[8 \cdot, 29 \bullet, 55]$} \\
\hline & Enterprise structure & 1 & {$[51]$} \\
\hline & Labor productivity/productivity & 6 & {$[29 \bullet, 40,51,52,72,91]$} \\
\hline & Gross value added, local value added & 5 & {$[8 \cdot, 21,29 \bullet, 41,55]$} \\
\hline & Net revenue & 1 & {$[90]$} \\
\hline
\end{tabular}

Some include all processes until the industry gate $[40,45$, 54-64].

When a system boundary should or has to be restricted to selected life cycle stages only, a cradle-to-gate perspective is possible [65]. The studies reported by [66-71] stopped at the landing and excluded the secondary transport. Most of the studies considered the regional boundaries of a country and even smaller regions in the country and investigated differences on the potential environmental impacts due to different forest management practices, while others investigated differences and similarities of the impacts of FO between different countries through case studies. 
The most commonly used metric of impact was energy use and the category "global warming potential", while few studies included forest biomass procurement cost in the analysis [40, 55, 57]. Energy use for selected biomass for energy supply systems varied considerably due to the system used (loose, bundled, or chipped logging residues), the forwarding distance, terrain difficulty, and biomass concentration [57]. For a specific species (hinoki cypress), the largest GHG emission values for the prefectures in the study was approximately 1.5 times higher than the lowest emissions. Fuel consumption proved to be the most relevant parameter in GHG emissions [72]. It contributed the most GHG emissions, while lubricants and maintenance had a rather small impact [40]. Innovation may play an important role in reducing fuel consumption. Tuomasjukka et al. [41] reported that when using smaller harvesters that are well adapted to thinning operations, fuel reductions ranged from $12 \%$ to $24 \%$. They also found that new chippers can provide lower fuel consumption and higher GHG emission reductions. Marchi et al. [29•] suggested that the new machines equipped with a hybrid electric power system present a promising method of lowering fuel consumption, while others recommend adopting efficient machines, appropriate technical system, and innovative products (e.g., biofuels) could help in the achievement of the GHG emission reduction $[73,74]$.

Eutrophication (excess nutrient availability in freshwater and marine ecosystems) and acidification (increased soil and water acidity) were also used as a metric of impact in many of the reviewed studies [e.g., 54, 63, 66-71]. In [71], intensive fertilization of fast-growing willow plantations had the highest effect in both eutrophication and acidification due to application of manure and nitrogen mineral fertilizer. For acidification, the combustion emissions (mostly NOx) from forest machinery were also important.

Besides the method of LCA, few others were used: Michelsen et al. [55] utilized a hybrid LCA process meaning that data gaps in the traditional life cycle inventory were filled in through a database, in this case, the Norwegian I-O that includes a sector-wise emission release. Buonocore et al. [54] integrated three methods (material flow accounting, energy accounting, and gross energy requirement) in the life cycle impact assessment in order to assess the environmental performance and sustainability of timber and wood chip production in Fiemme and Fassa Valleys, Province of Trento (Italy).

\section{Soil Compaction from Forest Operations}

By the mid-1990s, the role of forest soils in the context of SFM received increasing attention [26] and thus should be considered in each SIA. In a context of physical environment, soil disturbances caused by ground-based mechanized forest operations are normally classified as soil compaction (increase of soil bulk density), soil displacement (lateral and longitudinal displacement of soil caused by the machine running gear) commonly referred to as rutting, or a mixture of both disturbances. These soil disturbances can be problematic in several ways as they can affect machine trafficability within a harvest stand, influence surface runoff, inhibit root growth through lowered air exchange and water infiltration rates, reduce seedling and tree growth, etc. With the advent of increased machine size and payloads (total loaded masses of 20 to 50 metric tons) in combination with more frequent operations being performed in unfrozen soil conditions or on soils at high moisture content, protecting soil physical integrity is of paramount importance to assure forest sustainability.

\section{Disturbance Indicators}

Soil bulk density measurements obtained directly on machine operating trails pre- and post-machine traffic, predominantly through the use of soil cores, is the most commonly used indicator to quantify soil compaction. In fact, the only study appearing in the literature review using another device aside from soil cores was performed by Labelle and Jaeger [75], who utilized a non-destructive nuclear-moisture and density gauge (NMDG) to measure in-place soil bulk density and moisture content. NMDG allows for repeated measurements at the exact same location and at multi-depths since soil samples are not extracted from the site. However, NMDG equipment is expensive and requires radiation training while transportation of the equipment requires a dangerous goods permit. Because of differences in inherent soil properties, relative bulk density, relating the field bulk density to a maximum density achieved by the standard Proctor test, has also been used as a qualitative assessment instead of the frequently used absolute soil bulk density [75]. Through the use of the standard Proctor test, the same material (soil) collected from the site to be monitored is compacted [76] inside a mold with a fixed compaction energy. Therefore, the relative bulk density offers the possibility of comparing results from different test sites since all field densities are related to the respected standard Proctor test, obtained from the same material as the field densities.

Besides bulk density, soil penetration resistance was the second most commonly used indicator of soil disturbances and relied on the use of either analog [77-79] or digital penetrometers $[80,81]$ to collect data at different location points and various depths on the machine operating trails. Monitoring soil moisture content at the same time as recording soil penetration resistance is pivotal since the latter is highly influenced by moisture content present in the soil. Because soil bulk density is linked to porosity, water infiltration was also monitored in field studies performed by [77, 82] using double-ring infiltrometers.

Rutting was by far the soil disturbance indicator with the most variability in data gathering systems. These varied from 
conventional assessment techniques with the use of a fixed horizontal bar with height measurements made between soil break points and the bar [83], to portable laser scanners [78], photogrammetry [79], and a machine mounted scanner that used light-detection and ranging (LiDAR) [83]. In addition to providing continuous soil displacement measures, imagebased models proved to be valuable to determine the spatial extent and types of disturbances.

\section{Persistence}

Machine-induced soil compaction can persist from several years to decades depending on the severity of the impact, soil properties, and level of biological activity. Labelle and Jaeger [75] reported that soils (sandy silt and silty sand with gravel) exposed to frequent freeze and thaw cycles did not show any signs of natural rehabilitation during the first 5-years of monitoring following ground-based mechanized cut-to-length forest operations in Eastern Canada. Similarly, forest operations performed on silty clay and silty clay loam did not show any soil recovery to pre-impact levels after a 10 -year test period [82]. In a longer-term retrospective study, Ebeling et al. [84] reported soil recovery after 10-20 years following the last traffic event on silts with high biological activity (Cambisols on limestone), whereas recovery had not yet been completed after 40 years since the last traffic on loamy sandy soils (Podzols), with both tests performed in Lower Saxony, Germany. Ebeling et al. [84] also considered soil gas carbon dioxide as a proxy for soil structure recovery and in fact reported that its concentration was more appropriate to characterize soil compaction and ensuing recovery than soil bulk density.

\section{Mitigation Techniques and Best Management Practices}

Within the search criteria used, the most widely reported mitigation technique was the use of brush mats, originating from harvesting debris, which are placed on machine operating trails to act as a measure of trail protection to ensure the technical trafficability $[75,77,80,84-86]$. It is suggested to leave $20 \mathrm{~kg} \mathrm{~m}^{-2}$ of brush (green mass) on machine operating trails for adequate soil protection against dynamic peak loadings and the maximum amount available on segments of trails that are highly susceptible (areas with high soil moisture content, depressions, highly trafficked segments, etc.). Aside from using brush mats, Han et al. [80], Labelle and Jaeger [75, 85], and Ebeling et al. [84] supported the use of designated machine operating trails to concentrate traffic on pre-defined areas within a harvest site. The rationale for these suggestions stems from the fact that most machine-induced soil compaction occurs within the first few passes and that further machine traffic continues to increase soil density but at a slower increment.

\section{Societal Impacts of Forest Operations}

It is well known that forestry work, in particularly felling and extracting operations, is associated with a high risk of fatal accidents. Therefore, safety, health, and risk assessments seem to be the most popular ones among the societal aspects of FO. For instance, the review of Albizu-Urionabarrenetxea et al. [46] provided a comparison of the accident rates in the forestry sectors of eight selected European countries. The accident rate per $\mathrm{m}^{3}$ was lowest in Sweden and Finland and highest in Slovenia. The central European countries were in a medium range. Findings could be explained mainly due to the level of mechanization rates [22, 46, 51], which are commonly lower in mountainous regions [51]. The majority of accidents occurred when using chainsaws. Some studies also focused on types, causes, and frequencies of accidents [46, 87-89]. A correlation between the experience of forest workers and their accident rates was reported by Albizu-Urionabarrenetxea et al. [46] who determined that the risk significantly increased with decreasing experience. Interestingly, a correlation between the payment system and the risk of accidents was studied as well and revealed that the payment by piecework leads to an increase of accidents [46]. Laschi et al. [87] mentioned that the recovery period after accidents increases with rising age of workers and that there are correlations of weekdays and accident rates; in particular, the most accidents occur on Mondays. To reduce labor risks, training programs teaching the correct use of chainsaws, personal protective equipment, the prevention of falling down, etc. can be recommended [e.g., 46, 51]. In the review by Gallis [52], work-rest schedules were discussed. The author focused on the work-caused fatigue and its consequences such as several health problems and an increased risk of accidents. Gallis [52] emphasized the importance of pauses during FO and suggested the evaluation and optimization of work-rest schedules by using electromyography (EMG) and checklists of individual strength questionnaires (CIS).

Some studies determined the physical workload of chainsaw operators [47-49]. A measurable value to evaluate the physiological workload is the heart rate of forest workers. By using this method, Huber and Stampfer [49] evaluated cable yarding operations in combination with different work tasks of the chainsaw operators and defined the felling task as the one generating the highest physiological workload. Magagnotti and Spinelli [48] analyzed winching operations in coppice forests. They suggested the replacement of a steel cable with a synthetic rope, which offers the advantage of easier handling and further leads to a significantly reduced physiological workload [48]. In many FOs, topography and morphology can affect not only productivity but also workers' physiological workload. Spinelli et al. [50] found that introducing a slack puller did not result in any reduction of worker physiological workload during winching operations. In that 
study, the main stressor was moving up and down the slope, and the cable was a secondary stressor, which confirmed the negative impact of slope gradients. According to Caliskan and Caglar [47], food, fluid, and frequent short pauses throughout the day seem to be crucial for the condition of forest workers as well. Further, the personal protective equipment as well as an improvement of the forest machines support ergonomics and have a positive effect on the workload and occupational safety [51].

\section{Economic Impacts of Forest Operations}

There are hundreds of scientific papers describing productivity and costs in several timber and biomass supply chains but few of them include analysis of sustainability impacts in a broader evaluation. Lindner et al. [16] highlighted that many economic factors change at a rapid pace and the competitiveness of the sector can be influenced by fluctuating energy prices and the promotion of renewable energy use. On the other hand, future technology efficiency could change the results and economic indicators should be carefully verified and updated.

Most of the articles reporting sustainable analysis considered production costs (fixed and variable), total amount of wood harvested, time consumption, delays, gross domestic product, gross and local value added, trade, yearly net revenues of forest subjects, and fuel consumption [e.g., 8, 16, 40, $74,90,91]$. Cost and productivity can vary largely between countries and different scenarios related to different logging systems and assortments [21, 22, 41]. To give an example, Berg et al. [21] analyzed logging systems in different regions of Europe and showed that the production costs varied between the logging systems applied and also within similar systems. They were lowest for the manual systems in Eastern Europe and the manual and mechanized systems in southwest Europe, about two times higher for the mechanized systems being applied in the Nordic countries and about 2-5 times higher for mechanized systems being applied in central Europe.

Karvonen et al. [8•] illustrated the strengths and weaknesses of the main sustainability assessment tools and reported that economic tables are commonly available, but some information is difficult to obtain due to trade secrets, new products, and price fluctuations. In this respect, Berg et al. [21] claimed that economic reports from companies could be considered as sound and solid sources. Karvonen et al. [8•] suggested that economic indicators could have a different relevance among private-, company-, and national-level decision-makers.

Different technologies, harvesting methods, levels of intensity and mechanization, and allocations of products can influence costs and productivity [72, 74, 91]. Zhang et al. [40] highlighted that harvesting costs decrease with increasing removal intensity. Valente et al. [72] found that mechanized operations could reduce costs and increase productivity but, due to a higher use of fossil fuel, generate more GHG emissions than motor-manual harvesting. In their study, comparing a Norwegian and an Italian case, the authors found that extraction by cable yarding and transportation by truck were the most expensive operations. Similar findings were reported in a previous study [74]. On the other hand, cable yarding seems to be very efficient in terms of having a minimal impact on residual stand and soil.

Different harvesting systems can reduce costs and thus emissions. In Valente et al. [74], a whole-tree system employed in alpine conditions showed lower costs and emissions and therefore offered greater economic and environmental benefits than the traditional shortwood system. A higher productivity can result in higher hourly fuel consumption but lower fuel use $\left(1 / \mathrm{m}^{3} \mathrm{~s}\right)$. A recent study by Schweier et al. [91] showed similar results: a high productivity was reached with the full-tree harvesting method and the highest productivity with the fully mechanized full-tree harvesting system. In their analysis, the authors showed that the cumulative energy demand of fossil energy was lower when full-tree harvesting was applied.

\section{Discussion}

The literature about SIA with regard to forestry mainly focuses on forest management or on forest policy rather than on FO. In 2007, Ness et al. [7] stated that an analysis of the first SIAs carried out by Wilkinson et al. [92] concluded among other things that none of the assessments had followed the Commission guidelines completely. In 2019, we notice a development towards more holistic evaluations but can still confirm that there are few studies related to FO considering all pillars of sustainability [e.g., 21, 22, 41, 91]. Most studies are focused on different aspects of either environmental [e.g., 59, 61, 62] or environmental and economic impacts [e.g., 40, 57, 72]. Some indicators might be considered in more than one category, e.g., the risk of negative profit fits not only into the economic category but also into the societal one [90]. The fact that none of the studies addressed exclusively economic indicators can be explained by the use of the applied search strings "economic assessment" AND "Forest Operations". When searching for specific economic indicators, such as costs or productivity in combination with FO, several hundred scientific articles were reported. The same is true for the application of new techniques. We are aware that there is for example an increasing amount of studies dealing with the use of hybrid engines, but this trend is not reflected in our results because those studies were not selected when using the defined applied search strings. Instead, we present those studies that use SI to evaluate findings with regard to sustainability. 
From a methodological viewpoint, we noticed that studies including indicators of all categories (environmental, societal and economic) often used the method of EIA instead of an LCA to determine potential environmental impacts, which can be explained by the fact that SIAs are usually addressing a broader policy target group.

When focusing on soil compaction, it is clear that damage to soil physical properties do occur during ground-based mechanized operations and that the magnitude of this damage is dependent on machine and soil interactions. The use of soil relative density as a measure of qualitative assessment of the impacts of forest machines on soil density increases can provide valuable information that will allow more direct comparisons between test sites. Due to the potentially long period needed to naturally recover forest soils after machineinduced disturbances, mitigation techniques, such as the use of sufficient brush mats placed on machine operating trails, can help attenuate some of the negative effects of machine traffic on soils.

Surprisingly, when it comes to societal aspects, only a few studies could be identified. One reason might be the lack of data. However, an increase in publications was noticed in the last few years, which might be an indicator of the increasing relevance of societal aspects. It was suggested by Laschi et al. [87] that lower harvesting time and higher productivity allow a reduction of working hours per loggers and therefore a lower environmental input (or impact) related to transport of workers. It is important to include economics aspects in the concept of sustainability and encourage the appropriate forest mechanization that can improve efficiency, safety, and environmental protection.

\section{Suggestions to Enhance the Quality of SIAs}

- Relate the carbon dioxide emissions during FO to how much carbon is sequestered by vegetation and the soil during a selected amount of time, e.g., a year or a rotation period. Buonocore et al. [54] considered this and estimated that the total $\mathrm{CO}_{2}$ emissions released for timber and wood chips production and from the combustion of wood chips were roughly $7 \%$ of the amount of $\mathrm{CO}_{2}$ sequestered in the scenario with the maximum production level of timber and wood chips.

- Although climate change has global impact, other emissions such as acidification and eutrophication have local effects and should be related to the existing load of pollutants in the studied areas. In most of the reviewed studies, sets of generic values were used. None of the studies considered actual local values that were compared with the ones found in the studies.

- The substitution of fossil energy carriers by biomass for energy should be taken into account and the reduction of fossil carbon emissions should be stated in the studies, similar to [57 and 58] who discussed the environmental benefits of using biomass in substituting fossil fuels and building materials. The energy use of wood biomass may also imply impacts in terms of air quality when biomass is burned in facilities that lack technology for particle removal.

- We recommend carrying out sensitivity analysis, a technique in which input values of selected parameters are varied and the influence of the variations of the final results are assessed at least for the key processes of the life cycle inventory and to observe the effects on the identified hot spots of, e.g., harvesting system choice and fossil fuel requirements. Sensitivity analyses were conducted in many studies (e.g., $55,44)$. In the case of [55], the worst case scenario (smallest size of harvested logs, longest average distance to forest road, and longest transportation distance to the industry) showed four times larger environmental impacts than the best case scenario. Zhang et al. [40] showed, among other things, that a $10 \%$ increase in productivity of the harvesting operations would result in an approx. 9\% decrease of GHG emissions. Sensitivity analysis of machinery time consumption was also included in [63 and 66].

- Operators' skills and experience can have a significant effect on costs and productivity. Different operators can have higher or lower performance, fuel consumption, and frequencies of accidents according to their competence and motivation. Possible indicators such as years of experience and whether or not formal training was acquired should be considered.

- Often, fuel consumption is hourly based [e.g., 74] or is referred to cubic meters. We recommend reporting fuel consumption together with the quantity of wood produced to obtain a better understanding of the harvesting impact.

- Detailed data should be collected from on-board computers of machines. They assist most machine functions and record work parameters including fuel consumption, number of stems processed, diameters, lengths, etc.

- The severity of machine-induced compaction is commonly expressed as a change in absolute soil density (postimpact density minus pre-impact density). Instead of this conventional method, we recommend presenting soil density increases using the relative bulk density concept where field bulk densities are related to the maximum bulk density achieved through a standard Proctor test.

- Since most soil disturbance assessment techniques are performed post-impact when it is often too late to modify operations, we recommend further development of live monitoring techniques of soil disturbances. Machine-mounted LiDAR systems or other types of remote sensing technologies that scan the physical environment have shown promising results [83]. Linking results from the live scanning with soil-bearing capacity and local weather to permit onthe-fly adaptations of the material flow from the stand to the landings will be a crucial step to protect forest soils. 
- We support the inclusion of indicators that can measure the extra value of the forest, coming from wood products or process. Marchi et al. [29•] suggested considering the capability to pay for certified and sustainable wood products.

\section{Conclusions}

The role of SIA when considering economic, social, and environmental impacts will become more prevalent in studies reporting findings in bioeconomy and sustainability. SIA enforce sustainable management practices at local and global level. Therefore, SIA can help forest managers and policy makers to select the best technology or system alternative with regard to SFO and SFM. To be successful, reliable boundaries and parameters should be clearly defined and their implementation needs to be evaluated. Furthermore, indicators and tools should be updated and adapted to new and evolving situations. SIA is a tool that can give important input when defining best forest practices and the main driving factors for future development of forest operations promoting environmental, societal, and economic aspects.

Acknowledgments The authors thank Marie Klein for supporting the review.

Funding information JS is supported by the European Social Fund and by the Ministry of Science, Research and Arts Baden-Württemberg. DA is supported by the Bio4Energy Research Environment.

\section{Compliance with Ethical Standards}

Conflict of Interest The authors declare that they have no conflict of interest.

Human and Animal Rights and Informed Consent This article does not contain any studies with human or animal subjects performed by any of the authors.

Open Access This article is distributed under the terms of the Creative Commons Attribution 4.0 International License (http:// creativecommons.org/licenses/by/4.0/), which permits unrestricted use, distribution, and reproduction in any medium, provided you give appropriate credit to the original author(s) and the source, provide a link to the Creative Commons license, and indicate if changes were made.

\section{References}

Papers of particular interest, published recently, have been highlighted as:

- Of importance

1. Oesten G, Roeder A. Management von Forstbetrieben. Band 1: Grundlagen, Betriebspolitik. Remagen-Oberwinter: Dr. Kessel; 2002.
2. [UN] United Nations. 2012. The future we want. A/RES/66/288 http://www.un.org/ga/search/view doc.asp?symbol=A/RES/66/ 288\&Lang=E (Accessed 31 Jan 2019).

3. [UN] United Nations. 2015. Adoption of the Paris Agreement, FCCC/CP/2015/L.9/Rev.1, Paris. http://www.un.org/ga/search/ view_doc.asp?symbol=FCCC/CP/2015/L.9/Rev.1\&Lang=E (Accessed 31 Jan 2019).

4. [UN] United Nations. 2015. Transforming our World: the 2030 Agenda for Sustainable Development. A/RES/70/1. United Nations, 2015. https://sustainabledevelopment.un.org/post2015/ transformingourworld (Accessed 31 Jan 2019).

5. Villeneuve C, Tremblay D, Riffon O, Lanmafankpotin GY, Bouchard S. A systemic tool and process for sustainability assessment. Sustainability. 2017;9(10):1909. https://doi.org/10.3390/ su9101909.

6. Waas T, Hugé J, Block T, Wright T, Benitez-Capistros F, Verbruggen A. Sustainability assessment and indicators: tools in a decision-making strategy for sustainable development. Sustainability. 2014;6:5512-34. https://doi.org/10.3390/ su6095512.

7. Ness B, Urbel-Piirsalu E, Anderberg S, Olsson L. Categorising tools for sustainability assessment. Ecol Econ. 2007;60:298-508. https://doi.org/10.1016/j.ecolecon.2006.07.023.

8. Karvonen J, Halder P, Kangas J, Leskinen P. Indicators and tools for assessing sustainability impacts of the forest bioeconomy. For Ecosyst. 2017:4:2 This paper provides a comprehensive review about sustainability indicators and their application in sustainability impact assessments. One of the key conclusions is that although sufficient data are available to measure many indicators, the impacts may be very difficult to assess. Furthermore, some indicators, such as "biodiversity", are difficult to quantify in the first place. Therefore, the authors recommend a mix of different methods and approaches.

9. Tuomasjukka D, Athanassiadis D, Vis M. Threefold sustainability impact assessment method comparison for renewable energy value chains. Int J For Eng. 2017;28(2):116-22. https://doi.org/10.1080/ 14942119.2017.1318549.

10. [OECD] Organisation for economic co-operation and development. Guidance on Sustainability Impact Assessment, OECD Publishing, Paris OECD Publications; 2010. https://doi.org/10.1787/ 9789264086913-en.

11. Ercin E, Hoekstra AY. Carbon and water footprints: concepts, methodologies and policy responses. (World Water Assessment Programme; no. 4). Paris, France: United Nations Educational, Scientific and Cultural Organization (UNESCO); 2012.

12. de Groot RS, Wilson MA, Boumans RMJ. A typology for the classification, description and valuation of ecosystem functions, goods and services. Ecol Econ. 2002;41(3):393-408.

13. National Research Council of the national academies of the U.S. Sustainability assessment and management: process, tools, and indicators. In: Sustainability and the U.S. EPA, 1. Washington DC: The National Academies Press; 2011. p. 53-78. https://doi.org/10. 17226/13152.

14. Taisch M, Sadr V, May G, Stahl B. Sustainability Assessment Tools - State of Research and Gap Analysis. Vittal Prabhu; Marco Taisch; Dimitris Kiritsis. 20th Advances in Production Management Systems (APMS), Sep 2013, State College, PA, United States. Springer, IFIP Advances in Information and Communication Technology, AICT-415 (Part II), pp.426-434, 2013, Advances in production management systems. Sustainable production and service supply chains.

15. Sieber S, Amjath-Babu TS, Reidsma P, Koenig H, Piorr A, Bezlepkina I, et al. Sustainability impact assessment tools for land use policy advice: a comparative analysis of five research approaches. Land Use Policy. 2018;71:75-85. https://doi.org/10. 1016/j.landusepol.2017.11.042. 
16. Lindner M, Suominen T, Palosuo T, Garcia-Gonzalo J, Verweij P, Zudin S, et al. ToSIA-A tool for sustainability impact assessment of forest-wood-chains. Ecol Model. 2010;221:2197-205. https://doi. org/10.1016/j.ecolmodel.2009.08.006.

17. Palosuo T, Suominen T, Werhahn-Mees W, Garcia-Gonzalo J, Lindner M. Assigning results of the tool for sustainability impact assessment (ToSIA) to products of a forest-wood-chain. Ecol Model. 2010;221:2215-25. https://doi.org/10.1016/j.ecolmodel. 2010.03.02.

18. Rosén K, Lindner M, Nabuurs GJ, Paschalis-Jakubowicz P. Challenges in implementing sustainability impact assessment of forest wood chains. Eur J For Res. 2012;131(1):1-5. https://doi. org/10.1007/s10342-011-0571-8.

19. Päivinen R, Lindner M, Rosen K, Lexer MJ. A concept for assessing sustainability impacts of forestry-wood chains. Eur $\mathrm{J}$ For Res. 2012;131:7-19.

20. Werhahn-Mees W, Palosuo T, Garcia-Gonzalo J, Röser D, Lindner M. Sustainability impact assessment of increasing resource use intensity in forest bioenergy production chains. GCB Bioenergy. 2011;3:91-106. https://doi.org/10.1111/j.1757-1707.2010.01068.x.

21. Berg S, Fischbach J, Brüchert F, Poissonnet M, Pizzirani S, Varet A, et al. Towards assessing the sustainability of European logging operations. Eur J For Res. 2012;131:81-94. https://doi.org/10. 1007/s10342-011-0561-x.

22. Berg S, Schweier J, Brüchert F, Lindner M, Valinger E. Economic, environmental and social impact of alternative forest management in Baden-Württemberg (Germany) and Västerbotten (Sweden). Scand J Forest Res. 2014;29(5):485-98. https://doi.org/10.1080/ 02827581.2014 .927913$.

23. Carnus JM, Hengeveld GM, Mason B. Sustainability impact assessment of forest management alternatives in Europe: an introductory background and framework. Ecol Soc. 2012;17(4):49. https://doi. org/10.5751/ES-04838-170449

24. Lindner M, Werhahn-Mees W, Suominen T, Vötter D, Zudin S, Pekkanen M, et al. Conducting sustainability impact assessments of forestry-wood chains: examples of ToSIA applications. Eur J For Res. 2012;131:21-34. https://doi.org/10.1007/s10342-011-0483-7.

25. Arbter K. SEA and SIA - Two Participative assessment tools for sustainability. Published in: Conference proceedings of the EASY ECO 2 conference, may 15-17,2003. Vienna. pp. 175-181.

26. Schober A, Šimunović N, Darabant A, Stern T. Identifying sustainable forest management research narratives: a text mining approach. J Sustain For. 2018;37(6):537-54. https://doi.org/10.1080/ 10549811.2018.1437451.

27. Siry JP, Cubbage F, Potter KM, McGinley K. Current perspectives on sustainable forest management: North America. CFR. 2018;4: 138-49. https://doi.org/10.1007/s40725-018-0079-2.

28. Schanz H. Sustainable Forest management. In: Burley J, Evans J, Youngquist J, editors. Encyclopedia of Forest Sciences. Stadt. Amsterdam: Elsevier Academic Press; 2004.

29. Marchi E, Chung W, Visser R, Abbas D, Nordfjell T, Mederski PS. Sustainable Forest Operations (SFO): a new paradigm in a changing world and climate. Sci Total Environ. 2018;634:1385-97. https://doi.org/10.1016/j.scitotenv.2018.04.084 The objective of this recent review is to identify important issues concerning forest operations and to propose a new paradigm towards sustainability in a changing climate, work and environmental conditions.

30. Torgerson C. Systematic reviews. London: continuum international publishing group; 2003

31. Klein D, Wolf C, Schulz C, Weber-Blaschke G. 20 years of life cycle assessment (LCA) in the forestry sector: state of the art and a methodical proposal for the LCA of forest production. Int J Life Cycle Assess. 2015;20:556-75. https://doi.org/10.1007/s11367015-0847-1 This review was conducted to support the comparability between LCA studies. The authors analyzed existing LCA studies of forest production with special focus on Global Warming Potential and proposed some methodical approaches regarding the harmonization of system boundaries, functional units, considered processes, and allocation assumptions.

32. Uusitalo J. Introduction to Forest Operations and Technology. Hämeenlinna: JVP Forest Systems Oy; 2010.

33. Speidel G. Die Nachhaltigkeit [the sustainability]. AFJZ. 1971;142(12):295-9.

34. [OECD] Organisation for economic co-operation and development. Environmental Indicators. Towards Sustainable Development; Paris: OECD Publications; 2001. https://www.oecd.org/site/ worldforum/33703867.pdf (accessed on 06 September 2018).

35. MCPFE (Ministerial Conference on the Protection of Forests in Europe). Improved Pan-European indicators for sustainable forest management. MCPFE expert level meeting 7-8 Oct 2002, Vienna, Austria.

36. [EC] European Commission. Sustainable development indicators for the European Union. Eurostat, Luxemburg; 2005.

37. [UNDESA] United Nations Division for Sustainable Development Goals. Indicators of sustainable development: guidelines and methodologies. 3rd ed. New York: United Nations publication; 2007. https://sustainabledevelopment.un.org/index.php?page= view\&type $=400 \& n r=107 \&$ menu $=1515$ (accessed on 06 September 2018).

38. Linser S, Wolfslehner B, Asmar F, Bridge SRJ, Gritten D, Guadalupe V, et al. 25 years of criteria and Indicators for sustainable forest management: why some intergovernmental C\&I processes flourished while others faded. Forests. 2018;9:515. https:// doi.org/10.3390/ 99090515 .

39. Wolfslehner B, Linser S, Pülzl H, Bastrup-Birk A, Camia A, Marchetti M. Forest bioeconomy- a new scope for sustainability indicators. From science to policy 4: European Forest Institute; 2016.

40. Zhang F, Johnson DM, Wang J, Yu C. Cost, energy use and GHG emissions for forest biomass harvesting operations. Energy. 2016;114:1053-62.

41. Tuomasjukka D, Martire S, Lindner M, Athanassiadis D, Kühmaier M, Tumajer J, et al. Sustainability impacts of increased forest biomass feedstock supply - a comparative assessment of technological solutions. Int J For Eng. 2018;29(2):99-116. https://doi.org/10. 1080/14942119.2018.1459372.

42. Díaz-Yáñez O, Mola-Yudego B, Anttila P, Röser D, Asikainen A. Forest chips for energy in Europe: current procurement methods and potentials. Renew Sust Energ Rev. 2013;21:562-71.

43. Pülzl H, Prokofieva I, Berg S, Rametsteiner E, Aggestam F, Wolfslehner B. Indicator development in sustainability impact assessment: balancing theory and practice. Eur J For Res. 2012;131: 35-46. https://doi.org/10.1007/s10342-011-0547-8.

44. Garrett RD, Latawiec A. What are sustainability indicators for? In: Latawiec, editor. Sustainability Indicators. Berlin: De Gruyter; 2015. p. 1-15.

45. Cosola G, Grigolato S, Ackerman P, Monterotti S, Cavalli R. Carbon footprint of Forest operations under different management regimes. Croat J Eng. 2016;37:201-17.

46. Albizu-Urionabarrenetxea PM, Tolosana-Esteban E, RomanJordan E. Safety and health in forest harvesting operations. Diagnosis and preventive actions. A review. For Syst. 2013;22(3): 392-400. https://doi.org/10.5424/fs/2013223-02714.

47. Çalıșkan E, Çağlar S. An assessment of physiological workload of forest workers in felling operations. Afr J Biotechnol. 2010;9(35): 5651-8.

48. Magagnotti N, Spinelli R. Replacing steel cable with synthetic rope to reduce operator workload during $\log$ winching operations. Smallscale For. 2012;11:223-36. https://doi.org/10.1007/s11842-0119180-0. 
49. Huber C, Stampfer K. Efficiency of topping trees in cable yarding operations. Croat J For Eng. 2015;36(2):185-94.

50. Spinelli R, Aalmo GO, Magagnotti N. The effect of a slack-pulling device in reducing operator physiological workload during log winching operations. Ergonomics. 2015;58:781-90. https://doi. org/10.1080/00140139.2014.983184

51. Tsioras PA. 2012. Promotion of safety in Forest operations.

52. Gallis C. Increasing productivity and controlling of work fatigue in Forest operations by using prescribed active pauses: a selective review. Croat J For Eng. 2013;34(1):103-12.

53. International Organization for Standardization, 2006. ISO 14040: 2006. Environmental management - life cycle assessment - principles and framework.

54. Buonocore E, Häyhä T, Paletto A, Franzese PP. Assessing environmental costs and impacts of forestry activities: a multi-method approach to environmental accounting. Ecol Model. 2014;271:10-20.

55. Michelsen O, Solli C, Strømman AH. Environmental impact and added value in forestry operations in Norway. J Ind Ecol. 2008;12: 69-81. https://doi.org/10.1111/j.1530-9290.2008.00008.x.

56. Gonzalez-Garcia S, Berg S, Moreira MT, Feijoo G. Evaluation of forest operations in Spanish eucalypt plantations under a life cycle assessment perspective. Scand J For Res. 2009;24:160-72.

57. Eriksson L, Gustavsson L. Costs, $\mathrm{CO}_{2^{-}}$and primary energy balances of forest-fuel recovery systems at different forest productivity. Biomass Bioenergy. 2010;34:610-9.

58. Mathieu F, Francois N, Nicolas R, Frederic M. Quantifying the impact of forest management on the carbon balance of the forestwood product chain: a case study applied to even-aged oak stands in France. For Ecol Manag. 2012;279:176-88.

59. Murphy F, Devlin G, McDonnell K. Forest biomass supply chains in Ireland: a life cycle assessment of GHG emissions and primary energy balances. Appl Energ. 2014;116:1-8.

60. Pierobon F, Zanetti M, Grigolato S, Sgarbossa A, Anfodillo T, Cavalli R. Life cycle environmental impact of firewood production - a case study in Italy. Appl Energy. 2015;150:185-95.

61. Klein D, Wolf C, Schultz C, Weber-Blaschke G. Environmental impacts of various biomass supply chains for the provision of raw wood in Bavaria, Germany, with focus on climate change. Sci Total Environ. 2016;539:45-60.

62. Laschi A, Marchi E, González-García S. Forest operations in coppice: environmental assessment of two different logging methods. Sci Total Environ. 2016;562:493-503.

63. De la Fuente T, Athanassiadis D, Gonzalez-Garcia S, Nordfjell T. Cradle-to-gate life cycle assessment of forest supply chains: comparison of Canadian and Swedish case studies. J Clean Prod. 2017; 143:866-81.

64. Proto AR, Bacenetti J, Macri G, Zimbalatti G. Roundwood and bioenergy production from forestry: environmental impact assessment considering different logging systems. J Clean Prod. 2017;165:1485-98.

65. [EC] European Commission - Joint Research Centre - Institute for Environment and Sustainability (Eds.) (2010) International Reference Life Cycle Data System (ILCD) Handbook - General guide for Life Cycle Assessment - Detailed guidance. First edition. Luxembourg: Publications Office of the European Union; 2010.

66. Dias AC, Arroja L. Environmental impacts of eucalypt and maritime pine wood production in Portugal. J Clean Prod. 2012;37:36876.

67. Gonzalez-Garcia S, Bonnesoeur V, Pizzi A, Feijoo G, Moreira MT. The influence of forest management systems on the environmental impacts for Douglas-fir production in France. Sci Total Environ. 2013a;461-462:681-92.

68. González-García S, Krowas I, Becker G, Feijoo G, Moreira MT. Cradle-to-gate life cycle inventory and environmental performance of Douglas-fir roundwood production in Germany. J Clean Prod. 2013b;54:244-52
69. Gonzalez-Garcia S, Bonnesoeur V, Pizzi A, Feijoo G, Moreira MT. Comparing environmental impacts of different forest management scenarios for maritime pine biomass production in France. J Clean Prod. 2014a;64:356-67.

70. Gonzalez-Garcia S, Dias AC, Feijoo G, Moreira MT, Arroja L. Divergences on the environmental impact associated to the production of maritime pine wood in Europe: French and Portuguese case studies. Sci Total Environ. 2014b;472:324-37.

71. Gonzalez-Garcia S, Moreira MT, Dias AC, Mola-Yudego B. Cradle-to-gate life cycle assessment of forest operations in Europe: environmental and energy profiles. J Clean Prod. 2014c;66:188-98.

72. Valente C, Spinelli R, Hillring BG, Solberg B. Mountain forest wood fuel supply chains: comparative studies between Norway and Italy. Biomass Bioenergy. 2014;71:370-80.

73. Neupane B, Halog A, Dhungel A. Attributional life cycle assessment of woodchips for bioethanol production. J Clean Prod. 2011;19:733-41.

74. Valente C, Spinelli R, Hillring BG. LCA of environmental and socio-economic impacts related to wood energy production in alpine conditions: Valle di Fiemme (Italy). J Clean Prod. 2011;19(1718):1931-8.

75. Labelle ER, Jaeger D. Soil compaction caused by cut-to-length forest operations and possible short-term natural rehabilitation of soil density. Soil Sci Soc Am J. 2011;75(6):2314-29.

76. ASTM D698 12e2. Standard test methods for laboratory compaction characteristics of soil using standard effort $(12,400 \mathrm{ft}-\mathrm{lbf} / \mathrm{ft} 3$ $(600 \mathrm{kN}-\mathrm{m} / \mathrm{m} 3))$. ASTM International $13 \mathrm{pp}$.

77. Abdi E, Moghadamirad M, Hayati E, Jaeger D. Soil hydrophysical degradation associated with forest operations. For Sci Technol. 2017;13(4):152-7.

78. Giannetti F, Chirici G, Travaglini D, Bottalico F, Marchi E, Cambi M. Assessment of soil disturbance caused by forest operations by means of portable laser scanner and soil physical parameters. Soil Sci Soc Am J. 2017;81:1577-85.

79. Cambi M, Giannetti F, Bottalico F, Travaglini D, Nordfjell T, Chirici $\mathrm{G}$, et al. Estimating machine impact on strip roads via close-range photogrammetry and soil parameters: a case study in Central Italy. iForests. 2018;11:148-54.

80. Han S-K, Han H-S, Page-Dumroese DS, Johnson LR. Soil compaction associated with cut-to-length and whole-tree harvesting of a coniferous forest. Can J For Res. 2009;39:976-89.

81. Kleibl M, Klvač R, Pohořalý J. Impact of forest operation on soil compaction - San Rossore case study. Acta Universitatis Agriculturae et Silviculturae Mendelianae Brunensis. 2015;63: 1133-40.

82. Suryatmojo H. Recovery of forest soil disturbance in the intensive forest management system. Procedia Environ Sci. 2014;20:832-40.

83. Salmivaara A, Miettinen M, Finér L, Launiainen S, Korpunen H, Tuominen S, et al. Wheel rut measurements by forest machinemounted LiDAR sensors - accuracy and potential for operational application? Int J For Eng. 2018;29(1):41-52.

84. Ebeling C, Lang F, Gaertig T. Structural recovery in three selected forest soils after compaction by forest machines in Loew Saxony, Germany. For Ecol Manag. 2016;359:74-82.

85. Labelle ER, Jaeger D. Quantifying the use of brush mats in reducing forest machinery peak loads and surface contact pressures. Croat J For Eng. 2012;33(2):249-74.

86. Labelle ER, Jaeger D, Poltorak BJ. Assessing the ability of hardwood and softwood brush mats to distribute applied loads. Croat J For Eng. 2015;36(2):227-42.

87. Laschi A, Marchi E, Foderi C, Neri F. Identifying causes, dynamics and consequences of work accidents in forest operations in an alpine context. Saf Sci. 2016;89:28-35. https://doi.org/10.1016/j.ssci. 2016.05.017.s. 
88. Tsioras PA, Rottensteiner C, Stampfer K. Wood harvesting accidents in the Austrian State Forest Enterprise 2000-2009. Saf Sci. 2014;62:400-8. https://doi.org/10.1016/j.ssci.2013.09.016.

89. Melemez K. Risk factor analysis of fatal forest harvesting accidents: a case study in Turkey. Saf Sci. 2015;79:369-78. https://doi.org/10. 1016/j.ssci.2015.07.004.

90. Sacchelli S, Bernetti I, De Meo I, Fiori L, Paletto A, Zambelli P, et al. Matching socio-economic and environmental efficiency of woodresidues energy chain: a partial equilibrium model for a case study in Alpine area. J Clean Prod. 2014;66:431-42.

91. Schweier J, Spinelli R, Magagnotti N, Wolfslehner B, Lexer MJ. Sustainability assessment of alternative thinning operations in
Mediterranean softwood plantations. Forests. 2018;9:375. https:// doi.org/10.3390/f9070375.

92. Wilkinson D, Fergusson M, Bowyer C, Brown J, Ladefoged A, Monkhouse C, et al. Sustainable development in the European Commission's integrated impact assessments for 2003. Final report for the UK Department of the Environment, food and rural affairs (DEFRA). London: Institute for European Environmental Policy; 2004.

Publisher's Note Springer Nature remains neutral with regard to jurisdictional claims in published maps and institutional affiliations. 